IZA DP No. 4356

Perceptions and Labor Market Outcomes of Immigrants in Australia after 9/11

Deepti Goel

August 2009 


\title{
Perceptions and Labor Market Outcomes of Immigrants in Australia after 9/11
}

\author{
Deepti Goel \\ Institute for Financial Management and Research \\ and IZA
}

Discussion Paper No. 4356

August 2009

IZA

P.O. Box 7240

53072 Bonn

Germany

Phone: +49-228-3894-0

Fax: +49-228-3894-180

E-mail: iza@iza.org

\begin{abstract}
Any opinions expressed here are those of the author(s) and not those of IZA. Research published in this series may include views on policy, but the institute itself takes no institutional policy positions.

The Institute for the Study of Labor (IZA) in Bonn is a local and virtual international research center and a place of communication between science, politics and business. IZA is an independent nonprofit organization supported by Deutsche Post Foundation. The center is associated with the University of Bonn and offers a stimulating research environment through its international network, workshops and conferences, data service, project support, research visits and doctoral program. IZA engages in (i) original and internationally competitive research in all fields of labor economics, (ii) development of policy concepts, and (iii) dissemination of research results and concepts to the interested public.
\end{abstract}

IZA Discussion Papers often represent preliminary work and are circulated to encourage discussion. Citation of such a paper should account for its provisional character. A revised version may be available directly from the author. 
IZA Discussion Paper No. 4356

August 2009

\section{ABSTRACT \\ Perceptions and Labor Market Outcomes of Immigrants in Australia after 9/11}

I examine whether after the terrorist attacks of September 11, 2001 Muslim immigrants and immigrants who fit the Muslim Arab stereotype in Australia perceive a greater increase in religious and racial intolerance and discrimination compared to other immigrant groups. I also examine whether there is a differential change in their labor market outcomes. I find that after 9/11 there is a greater increase in the likelihood of Muslim men and of those who look like Muslims to report a lot of religious and racial intolerance and discrimination relative to other immigrants. Further, I do not find evidence that after 9/11 Muslims or their stereotypes show a differential change in the likelihood of looking for a new main job or of being employed. There is also no evidence of a differential change in hours worked or in wage incomes. This suggests that the Australian labor market did not react to attitudinal changes in society, at least in the immediate aftermath of 9/11.

JEL Classification: J61, J71

Keywords: discrimination, immigrants, September 2001, 9/11

Corresponding author:

Deepti Goel

Institute for Financial Management and Research

24 Kothari Rd

Nungambakkam

Chennai 600034

India

E-mail: deepti.goel@ifmr.ac.in 


\section{Introduction}

The repercussions of the attacks in the United States on September 11, $2001^{1}$ were felt worldwide. Immediately following 9/11 strikes on Muslims were reported from various parts of the world. The Federal Bureau of Investigation reports a seventeen-fold increase in antiMuslim crimes in the U.S. during 2001 (Human Rights Watch 2002). In the first nine weeks following the attacks the American-Arab Anti-Discrimination Committee reports over 700 violent incidents targeting Arab Americans, or those perceived to be Arab Americans, Arabs and Muslims (American-Arab Anti-Discrimination Committee 2003). The backlash of 9/11 was not confined to one nationality or religion, rather it targeted victims based on their perceived race, nationality, or religion. In the U.S., instances of hate violence included attacks on Sikhs and Indian-Americans (Human Rights Watch 2002 and American-Arab Anti-Discrimination Committee 2003). Targeting of Muslims and those who fit the Muslim stereotype spread beyond the United States. The Summary Report on Islamophobia in the EU (Allen and Nielsen 2002) notes a hardening of hostilities in the aftermath of September 11, 2001 towards Muslims in many EU countries, especially towards Muslim women and those who look of Muslim or Arab descent. BBC news reports that a mosque was destroyed in Brisbane, Australia in an apparent retaliation for the U.S. terror attacks and that other mosques were daubed with anti-Muslim graffiti (BBC 2001). All this suggests that 9/11 led to a surfacing of antagonistic attitudes towards the Muslim population, and towards those who look like Muslims, in many parts of the world.

In this paper I examine whether after 9/11 immigrants to Australia who are Muslim or who look of Muslim or Arab descent undergo a greater change in their perceptions about religious and racial intolerance and discrimination compared to other immigrant groups. ${ }^{2}$ If, as suggested above, there was a widespread increase in hostilities towards Muslims and their stereotypes, then, it is likely that the targeted groups would report a greater increase

\footnotetext{
${ }^{1}$ In the paper I sometimes refer to September 11, 2001 as 9/11.

${ }^{2}$ I sometimes refer to those who look of Muslim or Arab descent as 'Muslim-like'. I also refer to Muslim and Muslim-like immigrants as the 'targeted groups'.
} 
in religious and racial intolerance and discrimination around them compared to other immigrants. I also examine if after $9 / 11$ there was a differential change in the labor market behavior and outcomes of the targeted groups relative to other immigrants. Australia is one of the traditional settlement countries for international immigrants. In 2000 it attracted an inflow of 92.3 thousand permanent immigrants (OECD 2002) and in 2006 this number rose to 191.9 thousand (OECD 2008). An understanding of the effects of events like 9/11 on recent immigrants is important for both the immigrant cohorts of the future as well as for Australian policy makers, particularly if Australia is looking at immigration flows as a means to tackle skill shortages in its labor market.

There are other studies that have tried to identify the effects of $9 / 11$ on labor market outcomes of targeted groups. Davila and Mora (2005) study if the relative wages of certain groups that may be adversely affected by discrimination declined between 2000 and 2002 in the United States. They find a more than 20 percent decline in the relative wages of Middle Eastern Arab men, little change in the relative wages of Afghan, Iranian, and Pakistani men, and an improvement in relative wages of African Arab men. Kaushal, Kaestner, and Cordelia (2007) examine whether the September 11, 2001 attacks had any effect on employment, earnings, and residential mobility of first- and second- generation Arab and Muslim men in the United States. They find a 9-11 percent decline in the real wage and weekly earnings of these groups as well as reduced intrastate migration by these groups as a result of the terrorists' attacks. Gathering support from various official reports, Aslund and Rooth (2005) provide some evidence that after 9/11 attitudes in Sweden were more hostile towards immigrants from Africa and Middle East, presumably since these regions have a substantial Muslim population. However, using data on the entire Swedish working age population when they look at unemployment exit around 9/11, they do not find any evidence of increased discrimination against these minorities. They conclude that a possible explanation for their result could be that employers act rationally in their hiring decisions and do not respond to changes in attitudes. In this paper using a nationally representative micro survey I first 
examine whether the attacks of September 11, 2001 have a greater effect on the perceptions of targeted groups concerning racial and religious intolerance and discrimination in Australia relative to other groups. Such an effect would be a reflection of changes in attitudes of society towards these groups. Next, I examine whether effects on perceptions are accompanied by effects in the labor market. This paper thus relates to literature that examines the link between peoples' preconceptions and labor market discrimination (Bertrand and Mullainathan 2004; Darity and Mason 1998).

I use the Longitudinal Survey of Immigrants to Australia, LSIA, and adopt a difference in differences approach where identification comes from the timing of survey interviews. I find evidence to show that after 9/11 Muslim men and immigrants who look like Muslims have an increased likelihood of reporting a lot of religious and racial intolerance and discrimination in Australia relative to other immigrants. However, I do not find any evidence of a differential change in the labor market behavior and outcomes of Muslim or Muslim-like immigrants relative to other immigrant groups.

Section 2 explains the empirical strategy. Section 3 describes the dataset. Section 4 presents the empirical results and section 5 gives the conclusions.

\section{Empirical Framework}

\subsection{Methodology}

The timing of interviews in the dataset is used to identify whether after $9 / 11$ perceived discrimination grew faster among Muslim immigrants than among non-Muslims. The immigrants in the survey are interviewed twice. The first wave, wave1, of interviews is conducted approximately five months after arrival, and the second wave, wave2, about eighteen months after arrival. ${ }^{3}$ Each wave of interviews occurs over a one year period. In the sample the ear-

\footnotetext{
${ }^{3}$ The average time to wave 1 interview since arrival is 5.1 months. The standard deviation is 1.2 months and sample size is 3598. The average time to wave 2 interview since arrival is 17.5 months. The standard deviation is 1.1 months and sample size is 3591 .
} 
liest wave2 interview is conducted on February 28, 2001 and the last interview on February 28, 2002. September 11, 2001 therefore divides the wave2 interview period such that 0.53 of the period lies before it and 0.47 after. This helps in identifying the causal effects of 9/11 for the outcomes I study.

I use the following difference in differences approach,

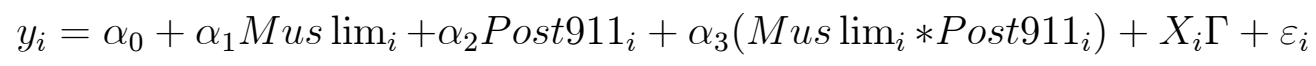

where $y_{i}$ is a binary dummy that captures individual $i$ 's perception of religious/racial intolerance/discrimination at the time of wave2. Mus $\lim _{i}$ and $P_{s o s t 911_{i}}$ are dummies for whether or not the individual is a Muslim and whether or not the wave2 interview was conducted after September 11, 2001, respectively. $X_{i}$ is a set of controls for individual characteristics like sex, age, education, visa status, country of birth, state of residence etc. $\varepsilon_{i}$ stands for all unobservable factors that affect an individual's perception. Thus, $\alpha_{3}$ is a difference in differences estimator (Blundell and Dias (2008) and Blundell, Dias, Meghir, and Reenen (2004) provide a good discussion of the difference in differences estimation approach). $\alpha_{3}$ is identified through variation in average perception between Muslims and non-Muslims before $9 / 11$, and comparison of this difference with variation in average perception between the same two groups after $9 / 11$. When analyzing perceptions on religious and racial intolerance and discrimination I estimate a Seemingly Unrelated Regression, SUR, system to be able to carry out joint significance test of the interaction terms for the four related variables on perceptions.

If after September 11 Muslim immigrants perceive a greater increase in racial and religious intolerance and discrimination compared to non-Muslim immigrants, then, the interaction term, Mus $\lim *$ Post911 should be positive and statistically significant. The underlying hypothesis in looking at the interaction term is that after $9 / 11$ targeted groups, Muslims in this case, will report greater increase in discrimination levels compared to non-targeted 
groups. If after $9 / 11$ all immigrants, irrespective of being targeted or not, perceive and report equally higher levels of discrimination in society, then only the Post911 variable will be statistically significant.

I also look at whether after 9/11 relative to other immigrants Muslim immigrants have a differential likelihood to look for a change in their main jobs ${ }^{4}$ and to be employed conditional on having been employed in wave1. I also examine whether they have a differential change in hours worked in their main job and in income from wages and salaries. To look at these labor market outcomes I estimate an equation similar to equation (1), where $y_{i}$ stands for the relevant outcome being studied.

In all cases above, I also estimate the equations by replacing the Muslim dummy with a Muslim-like dummy. The Muslim-like dummy takes the value 1 for immigrants from the Middle East, except Israel, and for immigrants from Afghanistan, Pakistan, India and Bangladesh. People who fall in the Muslim-like category may not be Muslims but they fit the media enforced stereotype of an Arab or Middle Eastern Muslim. Using the Muslim-like variable captures any effects of $9 / 11$ on attitudes and behavior that are expressed on the basis of stereotypes of Muslims or Arabs.

Finally, it should be noted that all immigrants in the sample arrive before September 11, 2001 and therefore the interaction coefficient is not biased due to selection at the time of granting entry into Australia.

\subsection{Timeline of events}

One potential cause for concern is that there could be other incidents that happened around September 11, 2001 and that had different effects on targeted and non-targeted groups, that are driving the results on the interaction term in equation (1). To see if this is the case, I look at the history of major events that may have affected Australia between March 2001 and February 2002, the period when the second wave of interviews was conducted.

\footnotetext{
${ }^{4}$ Main job is defined as the one in which the immigrant works the maximum number of hours per week.
} 
In May 2001, churches rebuked Prime Minister John Howard for failing to properly acknowledge the sufferings of thousands of Aborigines under past assimilation policy. However, it is unlikely that this event influenced the perceptions and outcomes of targeted groups any differently from the rest, and even more unlikely that it affected them differently after 9/11.

On 26th August 2001, a Norwegian freighter, the Tampa, rescued around 450 asylum seekers, most of them Afghans, from a sinking ferry in Australian waters. The Australian government refused to grant entry to these so called boat people and Australia's tough stance was criticized by the United Nations and various human rights groups. Although this particular incident happened close to $9 / 11$, and most of the asylum seekers were probably Muslims, Australia had been following a tough stance towards all those who arrived illegally to its shores for many years. Australia's policy of mandatory detention, whereby anyone arriving without visas or passports and claiming refugee status is automatically locked away while their application is being investigated, has been in place since 1992. Since Australia consistently held a strict position on illegal immigrants long before September 11, 2001, I do not think that the 'Tampa boat people' incident, although widely publicized, biases the interaction term between Mus lim and Post911 in my estimations.

The conservative Prime Minister, John Howard, won a third term in November 2001, and some say that this was largely due to strict new measures against boat people and illegal immigrants. In fact, some of these new measures and further tightening of policies towards asylum seekers were a reaction to $9 / 11$. In an interview following $9 / 11$, as a response to why there are detention centers in Australia for illegal migrants, the then Immigration Minister, Philip Ruddock, gave the following reply, "We have security issues, which have assumed far more importance now, post the tragic events in USA ...". Thus, if the more stringent measures against illegal arrivals were adopted because of increased security concerns felt after $9 / 11$, then, the interaction coefficient would be rightly picking up this effect. ${ }^{5}$

\footnotetext{
${ }^{5}$ The night-club bombing in Bali, Indonesia, which some refer to as Australia's September 11, happened in October 2002. The second wave of interviews was completed in February 2002 and therefore the Bali bombing does not influence this study.
} 
Finally, I control for interviews conducted in the month of Ramadan. Ramadan is a Muslim religious observance that takes place during the ninth month of the Islamic calendar. In 2001, Ramadan was observed between November 16 and December 15. It is considered the most venerated and blessed month of the Islamic year. Prayers, fasting, charity, and selfaccountability are especially stressed at this time. Thus, during this month of self-reflection and religious observances, the perceptions of Muslims may be affected and at the same time they may stand out as a group.

\section{Data and Descriptive Analysis}

I use the second cohort of the Longitudinal Survey of Immigrants to Australia, LSIA, undertaken by the Commonwealth Department of Immigration and Multicultural and Indigenous Affairs. The sampling unit of the LSIA is the Primary Applicant, PA. The PA is the person upon whom the approval to immigrate was based. The LSIA represents all PAs aged 15 years and over, who arrived in Australia as offshore visaed immigrants in the one year period September 1999 to August 2000. ${ }^{6}$ The group of persons who immigrate as part of the PA's visa application are known as the Migrating Unit, MU. To increase the sample size, I also include MU spouses in the analysis. As mentioned earlier, LSIA has two data collection waves, i.e. immigrants were interviewed twice. Wave1 covers the period prior to arrival and approximately the first six months since migration, while wave 2 covers the period six to eighteen months after migration. The wave1 sample consists of 3124 PAs and $1094 \mathrm{MU}$ spouses. Due to sample attrition between the waves, wave2 consists of 2649 PAs and 942 MU spouses.

According to the 2001 Census, Christians constitute the largest religious group, comprising 68 percent of the total Australian population. Muslims constitute 1.5 percent. Compared to their share in total Australian population, Muslims constitute a larger share of the LSIA immigrant cohort, 11.8 percent.

\footnotetext{
${ }^{6}$ The size of the population that LSIA represents is around 32,500 PAs.
} 
Table 1 presents some characteristics of the LSIA immigrant cohort at wave2. About 12 percent is Muslim. Although September 11, 2001 divides the wave2 interview period such that 0.53 of the interview period falls before that date and 0.47 after, only 26 percent of the wave 2 interviews are carried out after $9 / 11$. Thus, interviews are not uniformly spaced and a larger share of interviews is conducted before $9 / 11 .{ }^{7}$ Only 2 percent of the immigrant cohort at wave2 (approximately 70 observations) is Muslim and is interviewed after 9/11. The Muslim-like group, namely immigrants from the Middle East, except Israel, and from Afghanistan, Pakistan, India and Bangladesh constitutes about 19 percent of the cohort. About 4 percent (approximately 140 observations) is Muslim-like and is interviewed after 9/11. At wave2, 43 percent of the new immigrants have a Bachelor's or higher degree and 50 percent are on skilled visas. Immigrants from United Kingdom, China and India together comprise 35 percent of the LSIA immigrant cohort at wave2. At wave 2, 59 percent of the immigrant cohort is employed.

Panel A of Table 2 presents the questions, as worded in the LSIA questionnaire, on impressions of immigrants regarding religious and racial tolerance and discrimination in Australia at the time of wave2 interview. Responses to these questions are used to create the dependent variables concerning perceptions and are described in Panel B of table 2. A striking observation when comparing answers on perceptions of tolerance versus discrimination in Australia is that more people choose to give a categorical response when asked about tolerance, and a larger share of these responses is extreme. For example, there were 186 more responses for the question on religious tolerance compared to the one on religious discrimination and, conditional on a response, 9 percent felt that there was little religious tolerance in Australia, while only 3 percent felt that there was a lot of religious discrimination.

\footnotetext{
${ }^{7}$ In my estimations I control for months spent in the host country, which may vary quite a bit across the sample because of non-uniformly spaced interviews. On an average the time between wave1 and wave 2 interviews is 12.4 months with a standard deviation of 1.1 months and a sample size of 3591
} 


\section{Results}

\subsection{Perceptions}

Tables 3 and 4 present the SUR estimation results for the four responses on religious and racial perceptions. I use SUR to estimate a linear probability model where the sample includes only immigrants who gave all four responses. ${ }^{8}$ Table 3 includes the interaction of Post 9/11 with the Muslim dummy, while Table 4 does the same with the Muslim-like dummy.

In table 3 the coefficient on Post $9 / 11$ is positive and significant in all cases except religious intolerance. In the latter case it is negative but the magnitude is small and it is not statistically significant. Further the interaction between Muslim and Post 9/11 is always positive. This suggests that after $9 / 11$ all immigrant groups were more likely to report that there was little racial tolerance and a lot of religious and racial discrimination compared to their perception before $9 / 11$. For example in case of racial intolerance (column 3) after 9/11 the probability of reporting high level of racial intolerance in society increased by 8.7 percentage points among non-Muslims and it increased by $10.5(8.7+1.8)$ percentage points among Muslims.

Again in table 4 the Post 9/11 dummy is positive and significant in all cases except religious intolerance. In the latter case it is negative but not statistically significant. Also the interaction between Muslim-like and Post $9 / 11$ is positive for all four responses. This once again suggests that after $9 / 11$ all immigrant groups were more likely to report that there was little racial tolerance and a lot of religious and racial discrimination compared to their perception before $9 / 11$. Further, since the interaction term between Muslim-like and Post $9 / 11$ is also statistically significant at the one percent level for religious intolerance and religious discrimination, Muslim-like immigrants perceive greater increase after 9/11 in religious intolerance and discrimination relative to non Muslim-like immigrants. For example,

\footnotetext{
${ }^{8}$ The Bruesch and Pagan test of independence is rejected.
} 
before $9 / 11$ a Muslim-like immigrant is 8.1 percentage points less likely to report a high level of religious intolerance compared to a non-Muslim-like immigrant. However after 9/11, a Muslim-like immigrant is $5.2(-8.1+13.3)$ percentage points more likely to report a high level of religious intolerance compared to a non-Muslim-like immigrant.

In drawing conclusions from tables 3 and 4 it is important to test the joint significance of the four interaction terms in each table. The results for these tests are shown in table 5. The null hypothesis is that each of the four interaction terms is equal to zero, i.e. after 9/11 the change in the perceptions of Muslim or Muslim-like immigrants is no different compared to the change for non-Muslim or non-Muslim-like immigrant groups, respectively. The chi2 test is against the alternative hypothesis that at least one of the coefficients is not equal to zero. The more relevant alternative is that at least one of the coefficients is greater than zero; therefore, this test is more conservative in rejecting the null hypothesis. I cannot reject the null that the interaction terms are jointly insignificant for the Muslim case in table 3, while I reject the null of joint insignificance for the Muslim-like case in table 4.

Therefore, table 4 provides evidence to show that after $9 / 11$ there was greater perceived increase in religious and racial intolerance and discrimination among immigrants who fit the Muslim-Arab stereotype compared to other immigrant groups.

\subsubsection{Robustness checks}

Table 4 provides evidence to suggest that 9/11 had greater impact on perceptions of Muslimlike immigrants regarding religious and racial intolerance and discrimination around them relative to those who do not fit the Muslim or Arab stereotype. However, one needs to check if this result is solely driven by the September 2001 attacks or did other events around 9/11 influence peoples' perceptions. ${ }^{9}$ Two robustness checks are discussed below and the results

\footnotetext{
${ }^{9}$ There are not enough interviews between August 26, 2001, the day of the Tampa boat incident, and September 11, 2001, to be able to separate the effects of the Tampa boat incident from those of $9 / 11$. Also for reasons mentioned in section 2.2, I do not expect that the Tampa boat incident had a different impact on perceptions of Muslim-like immigrants compared to other immigrants.
} 
are shown in table 6 .

1. Narrowing window around $9 / 11$

I restrict the sample to a narrow window before and after $9 / 11$ to see if the results are influenced by other events besides $9 / 11$. If $9 / 11$ is entirely driving the results, the coefficients on the interaction terms should be similar in magnitude to those in table 4 even though standard errors may be larger due to the reduced sample size. Panel A of table 6 shows the results for Muslim-like immigrants where only immigrants interviewed in the three months before and after September 11 are included in the estimation. The magnitudes of the interaction coefficients are similar and in some cases are larger than corresponding coefficients in table 4, except for racial discrimination variable. The magnitude is much smaller for racial discrimination compared to table 4 , but this coefficient is not statistically significant in table 4. I conclude that the greater change in perceptions of Muslim-like immigrants after 9/11 regarding religious discrimination and religious intolerance is robust to this test.

\section{June 5 cutoff}

I use only those interviews conducted before September 11, 2001, and split this wave2 sample in half by choosing June 5 as the midpoint. I re-estimate the SUR specification in table 4 using a Post June 5 dummy instead of a Post 9/11 dummy. If the events of 9/11 are solely driving the results the interaction coefficients should not be significant in this specification. Panel B of table 6 presents the results of this exercise. For religious intolerance and discrimination and for racial intolerance the interaction terms are not significant at the five percent level. In column 4, the interaction term is positive and has a significant effect on perceptions concerning racial discrimination of Muslim-like immigrants after June 5 relative to all immigrants before June 5. The chi2 test of joint insignificance is rejected at the five percent level but not at the one percent level. ${ }^{10}$ However, as mentioned earlier

\footnotetext{
${ }^{10}$ Under the chi2 test for joint insignificance of the interaction terms, the chi2 statistic is 12.94 and the Prob > chi2 is 0.0116 .
} 
given the nature of the alternative hypothesis this test is conservative in rejecting the null hypothesis. Also, some coefficients have opposite signs and therefore it is difficult to interpret this inference test.

Overall, the first robustness check of narrowing the window around 9/11 supports the finding in table 4 that after 9/11 those who appear Muslim are more likely to report greater discrimination and intolerance in Australia relative to other immigrant groups. Although the second robustness check does not provide strong evidence to support that it is the events around 9/11 that are solely driving this finding, at the same time it does not contradict table 4.

\subsubsection{Non-response bias}

In all the estimations above an observation is included in the sample only when the individual gives a categorical response to the question being asked. If the immigrant chooses to answer, 'No opinion', which is also an option in the survey questionnaire, the observation is dropped from the regression. This can bias the coefficients if individuals who have an extreme opinion fear to state it and instead choose not to say anything at all. Table 7 examines whether non-response bias is a concern for the estimations so far. I once again estimate a SUR using the same specification as tables 3 and 4 . Conditional on being interviewed the dependent variables take the value 1 when the immigrant chooses 'No opinion' and 0 otherwise.

Panel A of table 7 shows that the interaction between Muslim and Post 9/11 is positive for all four responses but is never statistically significant. ${ }^{11}$ Panel B of table 7 tests for non response among the Muslim-like. It shows that after 9/11 Muslim-like immigrants show a statistically significant increase in non-response concerning their perceptions compared to other immigrants. The chi2 test of joint insignificance of the interaction terms is rejected under the alternate hypothesis of at least one coefficient being non-zero. ${ }^{12}$

\footnotetext{
${ }^{11}$ The chi2 test of joint insignificance against the alternative that at least one coefficient is non-zero, cannot be rejected. The chi2 statistic is 4.05 and the Prob > chi2 is 0.3988 .

${ }^{12}$ The chi2 statistic is 13.58 and Prob > chi2 is 0.0088 .
} 
Looking at the covariates in table 7, women and those who are not fluent in English are also more likely to not give an opinion relative to men and those who can speak English well, respectively.

In sum, relative to other groups there is evidence of significantly higher non-response after 9/11 among those who look like Muslims or Arabs when reporting their perceptions on religious and racial intolerance and discrimination. LSIA data is collected using in-depth personal interviews and it is not surprising that the targeted group chooses not to respond to sensitive questions. I expect that non-response among the targeted group biases results downwards.

\subsubsection{Differences by gender}

Muslim women, especially those wearing the burqha, may be more conspicuous compared to Muslim men because of their dress. They are therefore more likely to become targets of anti-Muslim attitudes and they may also feel more threatened in the wake of violence against Muslims following $9 / 11$. To examine if this is the case I re-estimate tables 3 and 4 by separating the sample according to gender. The results are shown in table 8 .

In the sample of males, the interaction terms are positive in all four cases and the hypothesis that they are jointly insignificant is rejected. ${ }^{13}$ For women, the coefficients on the interaction terms are in some cases larger than those for men, but the test for joint insignificance is not rejected. The results for women may suffer from non-response bias as women are more likely to suffer from non-response as seen in table 7. Also, the chi2 test is conservative in rejecting the null hypothesis.

\footnotetext{
${ }^{13}$ For the interaction terms between Muslim and Post 9/11, the chi2 statistic is 13.38 and Prob > chi2 is 0.0096. For the interaction terms between Muslim-like and Post 9/11, the chi2 statistic is 23.08 and Prob > chi2 is 0.0001 .
} 


\subsection{Labor Market Behavior and Outcomes}

The above analysis presents evidence that after 9/11 Muslim men and Muslim-like immigrants show a greater increase in their perceptions concerning religious and racial intolerance and discrimination relative to non-Muslim men and non-Muslim-like immigrants respectively. Given this finding, I next examine if this differential change in perceptions is concurrent with a differential change in their labor market behavior and outcomes.

\subsubsection{Search for a Change in Main Job}

Among the recent immigrant cohort 23 percent of those having a job at the time of wave 2 interview were looking for a change in their main job. Tables 9 and 10 respectively show the results for whether Muslims and Muslim-like immigrants show an increased likelihood of looking for a new main job after 9/11 compared to other immigrants. This may be the case if after $9 / 11$ they are more likely to be dissatisfied with their work environment compared to other immigrant groups. On the other hand, targeted groups may show a decreased tendency for job change if they feel that their job prospects have been more adversely affected compared to other groups.

Conditional on being employed at wave 2 interview, the dependent variable takes the value 1 if the immigrant reports that he is searching for a new main job and 0 otherwise. The tables report linear probability model coefficients. In column 2, I additionally control for whether the current main job was found using the immigrant's social network, i.e. through family or friends and in column 3 I also include controls for occupation. Surprisingly, the interaction terms between Muslim/Muslim-like and Post 9/11 have opposite signs. Table 9 shows that the interaction between Muslim and Post 9/11 is positive and insignificant in all specifications. However, the magnitude of the coefficients is not trivial. Before 9/11 Muslims are 9 percentage points less likely to be looking for a change in main job compared to non-Muslims, whereas after 9/11 Muslims are $5(-9.2+13.9)$ percentage points more likely to do so compared to non-Muslims. Table 10 shows that the interaction between Muslim- 
like and Post 9/11 is negative and is significant at the ten percent level in column 3. Before 9/11 Muslim-like immigrants are 13 percentage points less likely to be looking for a change in main job compared to non-Muslim-like immigrants (this is not statistically significant), while after $9 / 11$ they are $30(13.2+16.6)$ percentage points less likely to do so compared to non-Muslim-like immigrants.

Thus, for Muslim or for Muslim-like immigrants there is no evidence of differential job search behaviour after 9/11 compared to other immigrant groups.

\subsubsection{Employment Status}

59 percent of the recent immigrant cohort is employed at wave 2 interview. Table 11 shows whether there is a differential change in the likelihood of being employed for Muslims and Muslim-like immigrants after 9/11 compared to other immigrant groups. One would expect to see a greater decrease in employment rates of targeted groups if after $9 / 11$ they face higher rates of being fired from their jobs and/or lower rates of being recruited into new jobs. Conditional on being employed at wave1 interview, the dependent variable takes the value 1 if the immigrant is employed at wave 2 interview and 0 otherwise. The table reports linear probability model coefficients. The interaction between Muslim and Post 9/11 and that between Muslim-like and Post 9/11 are both positive but never statistically significant.

Thus, there is no evidence of lower employment rates after 9/11 for Muslims or Muslimlike groups compared to other immigrant groups.

\subsubsection{Hours Worked per Week in Main Job}

On an average a recent immigrant works for about 38 hours per week in his main job. Table 12 examines whether after $9 / 11$ there is a differential change in this variable for Muslims or Muslim-like immigrants compared to other groups. Table 12 presents the results for an OLS where the dependent variable is hours worked per week in the main job, conditional on having a job. In columns 2 and 4 I additionally control for occupation. 
Column 1 shows that before 9/11 Muslims work 6 hours less per week in their main jobs compared to other immigrant groups, but after 9/11 they work almost the same number of hours as other immigrants $(-6.03+5.74)$, although the interaction term is not statistically significant.

Column 3 shows that before $9 / 11$ Muslim-like immigrants work 1.5 hours more per week in their main jobs compared to other immigrant groups (this is not statistically significant), but after $9 / 11$ they work $6(1.5+4.5)$ hours more per week compared to other immigrant groups (again the interaction between Muslim-like and Post 9/11 is not statistically significant).

Once again, there is no evidence of a differential change in hours worked after $9 / 11$ for Muslims or Muslim-like groups compared to other immigrants. ${ }^{14}$

\subsubsection{Income from Wages}

LSIA captures income per week from wages and salaries but the information is interval coded. The modal weekly income from wages and salaries is 1230.5 Australian dollars. In table 13 I present the results of an ordered probit regression where the latent variable is logarithm of wages. In columns 2 and 4 I control for occupation. Column 2 shows that before 9/11 Muslim immigrants earn 22 percent lower wages than non-Muslim immigrants while after 9/11 they earn 26 percent lower wages. Similarly, column 4 shows that before 9/11 Muslimlike immigrants earn 21 percent higher wages compared to non-Muslim like immigrants, while after 9/11 they earn 19 percent higher wages. The interaction term between Muslim/Muslimlike and Post $9 / 11$ is never statistically significant. Thus, there is no evidence of differential change in wage income after $9 / 11$ for these groups compared to other immigrants.

The coefficients for Post 9/11 are negative and are statistically significant in all cases except column 4. When I control for occupation the coefficient increases. This suggests that

\footnotetext{
${ }^{14}$ In column 4 when I control for occupation there an increase of 1.3 hours per week in the magnitude of the interaction coefficient for Muslims and there is small decrease of 0.7 hours per week for Muslim-like immigrants. This suggests that after $9 / 11$ Muslims show a greater tendency to be in occupations that entail smaller work hours while Muslim-like immigrants show a greater tendency to be in occupations that have more work hours.
} 
after 9/11 people moved to occupations that paid lower wages.

In conclusion, the results in tables 9 to 13 show that $9 / 11$ did not have any differential effects on the labor market behavior and outcomes of the targeted groups relative to other immigrant groups. This conforms with the finding in Aslund and Rooth (2005) for Sweden where they do not find any evidence of increased labor market discrimination against minorities in the aftermath of $9 / 11$ attacks.

\subsection{Attrition bias}

Finally, if Muslims or other immigrants most affected by the events of 9/11 were not interviewed post September 11, i.e. if there was higher attrition among the targeted groups after 9/11 relative to others, then, this may bias the results seen so far. Table 14 investigates this possibility. It shows the reasons for attrition between the two waves for the PAs who are the sampling units in LSIA. The first column gives this information for the full sample. About 14 percent of the wave1 sample is not interviewed in wave2. Columns 2 and 3 show that both the Muslim and non-Muslim groups have about 14 percent attrition between waves. Similarly columns 4 and 5 show that while the attrition rate was 7 percent for the Muslim-like group, it was about 16 percent for the non-Muslim-like population.

To investigate this further, the left hand side of table 15 shows the sample fractions for a cross tabulation between religious identity and whether the wave 2 interview was conducted in the pre- or post- September 11, 2001 interview period. The right hand side shows the same information for the wave1 sample, using August 16, 2000 as the cut off, because it divides the wave1 interview period in exactly the same proportion as September 11 divides the wave 2 period. ${ }^{15}$ The top panel shows that there is a one percentage point drop in the share of Muslim immigrants in the post-9/11 interview period compared to their share in the corresponding wave1 period (from 3 percent in wave1 to 2 percent in wave2). The lower

\footnotetext{
${ }^{15}$ September 11, 2001 divides the wave2 interview period such that 0.53 of the period lies before it and 0.47 after. August 16, 2000 divides the wave1 interview period in exactly this proportion.
} 
panel shows that the share of Muslim-like immigrants interviewed after 9/11 remained the same as their share in the corresponding wave1 period ( 6 percent in both cases). Thus, for the Muslim population there is some evidence of attrition bias which I suspect would bias the interaction term downwards. The cross tabulations do not suggest attrition bias for the Muslim-like population.

In all the estimations I use wave2 weights designed by the LSIA to correct for attrition bias. To the extent that these weights take account of attrition and that a key variable in calculating these weights is country of origin which is correlated with being Muslim, my estimates should not suffer from attrition bias.

\section{Conclusion}

In this paper I first examine whether after the September 11, 2001 bombings in the United States there is a significantly different change in the perceptions of Muslim immigrants to Australia regarding religious and racial intolerance and discrimination relative to non-Muslim immigrants. I also study whether this is the case for immigrants from the Middle East (except Israel) and South Asia, who may not be Muslim, but, who fit the media enforced stereotype of a Muslim or an Arab. I also examine whether after 9/11 there is a differential change in the labor market behavior and outcomes of the targeted groups relative to other immigrants. The labor market outcomes I analyze here are the likelihood of searching for a change in main job, the likelihood of being employed, hours worked in main job and income from wages. I use a nationally representative survey of immigrants to Australia and adopt a difference in differences approach where identification comes from the timing of survey interviews around $9 / 11$.

There is evidence to show that after 9/11 Muslim men and those who fit the Muslim Arab stereotype perceive a greater increase in religious and racial intolerance and discrimination in Australia relative to other immigrants. If such perceptions are based on real life experiences, 
then, this finding suggests that relative to other immigrants, Muslim men and those who can be typecast as Muslims or Arabs experienced greater discrimination in the months immediately following $9 / 11$.

Finally, for the labor market outcomes analyzed in this paper, I find no evidence of differential change in these outcomes after $9 / 11$ for Muslim or for Muslim-like immigrants compared to other immigrant groups. Specifically, there is no differential change in the likelihood of looking for a new main job or of being employed. There is also no evidence of differential change in hours worked or in wage incomes for the targeted groups. This suggests that the Australian labor market did not respond to attitudinal changes in society, atleast in the six month period following the September 2001 attacks in the United States. 


\section{References}

Allen, Christopher, and Jorgen S. Nielson. 2002. "Summary Report on Islamophobia in the EU after 11 September 2001." European Monitoring Centre on Racism and Xenophobia.

American-Arab Anti-Discrimination Committee. 2003. "Report on Hate Crimes and Discrimination Against Arab Americans." American-Arab Anti-Discrimination Committee Report.

Aslund, Olof, and Dan-Olof Rooth. 2005. "Shifts in attitudes and labor market discrimination: Swedish experiences after 9-11." Journal of Population Economics 18(4): 603-629.

BBC. 2001. "Australian Muslims Attacked."http://news.bbc.co.uk/2/hi/asia-pacific/1560639.stm

Bertrand, Marianne, and Sendhil Mullainathan, 2004. "Are Emily and Greg More Employable than Lakisha and Jamal? A Field Experiment on Labor Market Discrimination." American Economic Review 94(4):991-1013.

Blundell, Richard, and Monica Costa Dias. "Alternative Approaches to Evaluation in Microeconomics." IZA Discussion Paper No. 3800.

Blundell, Richard, Monica Costa Dias, Costas Meghir, and John Van Reenen. 2004. "Evaluating the Employment Impact of a Mandatory Job Search Assistance Program." Journal of European Economics Association 2 (4).

Davila, Alberto, and Marie T. Mora. 2005. "Changes in Earnings of Arab Men in the U.S. between 2000 and 2002. Journal of Population Economics 18:587-601.

Darity, William A., Jr., and Patrick L. Mason. 1998. "Evidence on Discrimination in Employment: Codes of Color. Codes of Gender." Journal of Economic Perspectives 12(2): 63-90.

Human Rights Watch. 2002. "'We are Not the Enemy': Hate Crimes against Arabs, Muslims, and Those Perceived to be Arab or Muslim after September 11." Human Rights Watch Report 14 (6G) (November).

Kaushal, Neeraj, Robert Kaestner, and Cordelia Reimers. 2007. "Labor Market Effects of September $11^{\text {th }}$ on Arab and Muslim Residents of the United States." The Journal of Human Resources XLII 2.

OECD. 2002. "Trends in International Migration." OECD 2002 edition.

OECD. 2008. "International Migration Outlook: SOPEMI." OECD 2008 edition. 
Table 1: Characteristics of LSIA Immigrant Cohort at wave2

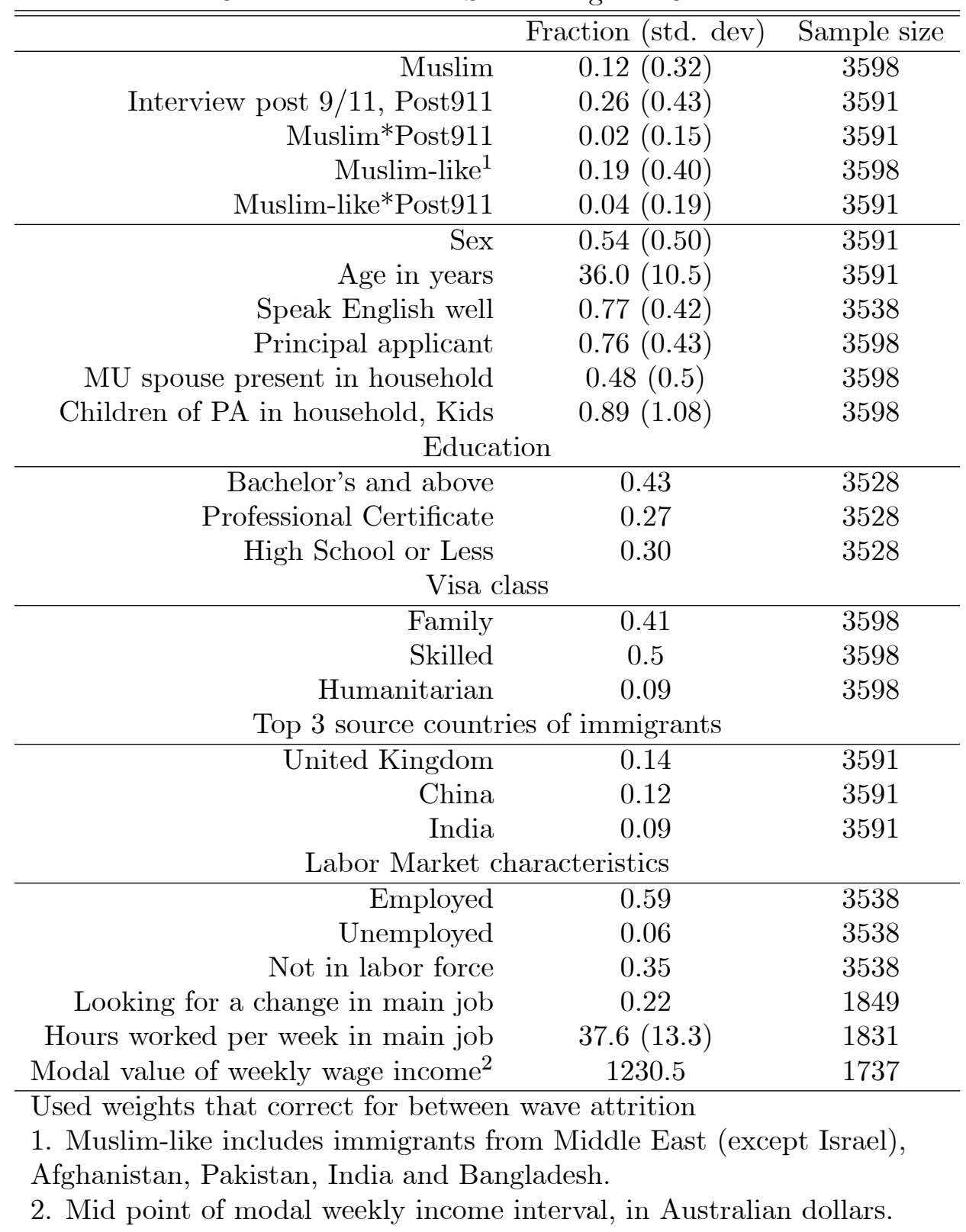


Table 2: Perceptions about living in Australia, at wave2

Panel A: Wording of questions on perception ${ }^{1}$

a. Do people in Australia display a lot of tolerance towards people of other religions, some or only a little?

b. Is there a lot of religious discrimination in Australia, some or only a little?

c. Do people in Australia display a lot of tolerance towards people of other races, cultures and countries, some or only a little?

d. Is there a lot of racial discrimination in Australia, some or only a little?

Panel B: Binary dependent variable(conditional on an opinion)

\begin{tabular}{r|lcc} 
Variable & Response Description & Fraction & Sample size \\
\hline tolerance & 1=Little tolerance, 0=Some or Lot & 0.09 & 3311 \\
mination & 1=Lot, 0=Some or Little & 0.03 & 3125 \\
tolerance & 1=Little tolerance, 0=Some or Lot & 0.09 & 3382 \\
mination & 1=Lot, 0=Some or Little & 0.04 & 3286 \\
\hline
\end{tabular}

Religious intolerance $\quad 1=$ Little tolerance, $0=$ Some or Lot $\quad 0.09 \quad 3311$

Religious discrimination $\quad 1=$ Lot, $0=$ Some or Little $\quad 0.03 \quad 3125$

Racial intolerance $\quad 1=$ Little tolerance, $0=$ Some or Lot $\quad 0.09 \quad 3382$

Racial discrimination $\quad 1=$ Lot, $0=$ Some or Little $\quad 0.04 \quad 3286$

Used weights that correct for between wave attrition.

1. For each of these questions, the respondent could choose "No opinion". 
Table 3: Perceptions of Muslims after 9/11, SUR

\begin{tabular}{|c|c|c|c|c|}
\hline \multirow[t]{2}{*}{ Dependent variable } & $\begin{array}{l}\text { Religious } \\
\text { intolerance }\end{array}$ & $\begin{array}{c}\text { Religious } \\
\text { discrimination }\end{array}$ & $\begin{array}{c}\text { Racial } \\
\text { intolerance }\end{array}$ & $\begin{array}{c}\text { Racial } \\
\text { discrimination }\end{array}$ \\
\hline & (1) & $(2)$ & (3) & $(4)$ \\
\hline \multirow[t]{2}{*}{ Muslim } & 0.016 & -0.007 & -0.017 & -0.007 \\
\hline & {$[0.021]$} & {$[0.011]$} & {$[0.020]$} & {$[0.014]$} \\
\hline \multirow[t]{2}{*}{ Post 911} & -0.007 & $0.035^{* *}$ & $0.087 * * *$ & $0.068 * * *$ \\
\hline & {$[0.028]$} & {$[0.015]$} & {$[0.028]$} & {$[0.019]$} \\
\hline \multirow[t]{2}{*}{ Muslim*Post911 } & $0.076^{*}$ & 0.025 & 0.018 & $0.054^{*}$ \\
\hline & {$[0.045]$} & {$[0.025]$} & {$[0.045]$} & {$[0.031]$} \\
\hline \multirow[t]{2}{*}{ Ramadan } & -0.016 & 0.010 & -0.013 & 0.002 \\
\hline & {$[0.025]$} & {$[0.014]$} & {$[0.025]$} & {$[0.017]$} \\
\hline \multirow[t]{2}{*}{ Muslim*Ramadan } & $-0.156^{*}$ & -0.040 & 0.051 & 0.016 \\
\hline & {$[0.091]$} & {$[0.050]$} & {$[0.090]$} & {$[0.061]$} \\
\hline \multirow[t]{2}{*}{ Female } & -0.000 & $0.016^{* *}$ & -0.003 & $0.016^{* *}$ \\
\hline & {$[0.012]$} & {$[0.007]$} & {$[0.012]$} & {$[0.008]$} \\
\hline \multirow[t]{2}{*}{ Age } & 0.000 & $-0.001^{*}$ & $-0.002^{* * *}$ & $-0.001^{* * *}$ \\
\hline & {$[0.001]$} & {$[0.000]$} & {$[0.001]$} & {$[0.000]$} \\
\hline \multirow[t]{2}{*}{ Speak English well } & $0.034^{* *}$ & -0.011 & $-0.060 * * *$ & $-0.038 * * *$ \\
\hline & {$[0.017]$} & {$[0.009]$} & {$[0.017]$} & {$[0.012]$} \\
\hline \multirow[t]{2}{*}{ Principal applicant } & -0.018 & 0.005 & -0.010 & $0.037^{* * *}$ \\
\hline & {$[0.016]$} & [0.009] & {$[0.016]$} & {$[0.011]$} \\
\hline \multirow[t]{2}{*}{ MU spouse in hhld } & -0.005 & -0.008 & 0.017 & $0.024^{* *}$ \\
\hline & {$[0.018]$} & {$[0.010]$} & {$[0.018]$} & {$[0.012]$} \\
\hline \multirow[t]{2}{*}{ Kids } & 0.000 & 0.002 & -0.002 & -0.002 \\
\hline & {$[0.005]$} & [0.003] & {$[0.005]$} & {$[0.004]$} \\
\hline \multirow[t]{2}{*}{ Months in Australia } & $0.009^{*}$ & $-0.013^{* * *}$ & -0.003 & $-0.006^{*}$ \\
\hline & {$[0.005]$} & {$[0.003]$} & {$[0.005]$} & {$[0.003]$} \\
\hline \multirow[t]{2}{*}{ Professional Cert. } & -0.003 & $0.024^{* * *}$ & $-0.026^{*}$ & $-0.017^{*}$ \\
\hline & {$[0.013]$} & {$[0.007]$} & {$[0.013]$} & {$[0.009]$} \\
\hline \multirow[t]{2}{*}{ High school or less } & $0.028^{*}$ & $-0.016^{*}$ & -0.021 & $-0.019^{*}$ \\
\hline & {$[0.015]$} & {$[0.008]$} & {$[0.015]$} & {$[0.010]$} \\
\hline \multirow[t]{2}{*}{ Family visa } & $0.043^{* *}$ & $0.022 * *$ & $0.056^{* * *}$ & $0.024^{* *}$ \\
\hline & {$[0.018]$} & {$[0.010]$} & {$[0.017]$} & {$[0.012]$} \\
\hline \multirow[t]{2}{*}{ Humanitarian visa } & $0.078^{* * *}$ & 0.009 & 0.024 & $0.039 * *$ \\
\hline & {$[0.027]$} & {$[0.015]$} & {$[0.027]$} & {$[0.018]$} \\
\hline Quarter of arrival & Yes & Yes & Yes & Yes \\
\hline Labor force status & Yes & Yes & Yes & Yes \\
\hline COB groups & Yes & Yes & Yes & Yes \\
\hline Interview state & Yes & Yes & Yes & Yes \\
\hline Observations & 2916 & 2916 & 2916 & 2916 \\
\hline
\end{tabular}

Used weights that correct for between wave attrition. Bachelor's and above and Skilled visa are omitted categories for education and visa status. Standard errors in brackets; * significant at $10 \%$; ** significant at $5 \%$; *** significant at $1 \%$ 
Table 4: Perceptions of Muslim like after 9/11, SUR

\begin{tabular}{|c|c|c|c|c|}
\hline Dependent variable & $\begin{array}{c}\text { Religious } \\
\text { intolerance } \\
(1)\end{array}$ & $\begin{array}{c}\text { Religious } \\
\text { discrimination } \\
(2)\end{array}$ & $\begin{array}{c}\text { Racial } \\
\text { intolerance } \\
(3)\end{array}$ & $\begin{array}{c}\text { Racial } \\
\text { discrimination } \\
(4)\end{array}$ \\
\hline \multirow[t]{2}{*}{ Muslim-like } & $-0.081^{* *}$ & 0.012 & $-0.087^{* *}$ & -0.002 \\
\hline & {$[0.034]$} & {$[0.019]$} & {$[0.034]$} & {$[0.023]$} \\
\hline \multirow[t]{2}{*}{ Post 911} & -0.025 & $0.026^{*}$ & $0.086^{* * *}$ & $0.068 * * *$ \\
\hline & {$[0.028]$} & {$[0.016]$} & {$[0.028]$} & {$[0.019]$} \\
\hline \multirow[t]{2}{*}{ Muslim-like*Post911 } & $0.133^{* * *}$ & $0.073^{* * *}$ & 0.029 & 0.034 \\
\hline & {$[0.039]$} & {$[0.021]$} & {$[0.038]$} & {$[0.026]$} \\
\hline \multirow[t]{2}{*}{ Ramadan } & 0.007 & 0.021 & -0.012 & -0.014 \\
\hline & {$[0.027]$} & {$[0.015]$} & {$[0.026]$} & {$[0.018]$} \\
\hline \multirow[t]{2}{*}{ Muslim-like*Ramadan } & $-0.215^{* * *}$ & $-0.101^{* * *}$ & 0.015 & $0.081^{*}$ \\
\hline & {$[0.065]$} & {$[0.036]$} & {$[0.064]$} & {$[0.044]$} \\
\hline \multirow[t]{2}{*}{ Female } & -0.004 & $0.016^{* *}$ & -0.004 & $0.016^{* *}$ \\
\hline & {$[0.012]$} & {$[0.007]$} & {$[0.012]$} & {$[0.008]$} \\
\hline \multirow[t]{2}{*}{ Age } & -0.000 & $-0.001^{*}$ & $-0.002^{* * *}$ & $-0.001^{* * *}$ \\
\hline & {$[0.001]$} & {$[0.000]$} & {$[0.001]$} & {$[0.000]$} \\
\hline \multirow[t]{2}{*}{ Speak English well } & $0.030^{*}$ & -0.011 & $-0.063^{* * *}$ & $-0.038^{* * *}$ \\
\hline & {$[0.017]$} & {$[0.009]$} & {$[0.017]$} & {$[0.012]$} \\
\hline \multirow[t]{2}{*}{ Principal applicant } & -0.018 & 0.005 & -0.010 & $0.037^{* * *}$ \\
\hline & {$[0.016]$} & {$[0.009]$} & {$[0.016]$} & {$[0.011]$} \\
\hline \multirow[t]{2}{*}{ MU spouse in hhld } & -0.006 & -0.009 & 0.019 & $0.023^{*}$ \\
\hline & [0.018] & {$[0.010]$} & {$[0.018]$} & {$[0.012]$} \\
\hline \multirow[t]{2}{*}{ Kids } & 0.001 & 0.002 & -0.002 & -0.001 \\
\hline & {$[0.005]$} & {$[0.003]$} & {$[0.005]$} & {$[0.004]$} \\
\hline \multirow[t]{2}{*}{ Months in Australia } & $0.010^{* *}$ & $-0.013^{* * *}$ & -0.003 & $-0.006^{* *}$ \\
\hline & {$[0.005]$} & {$[0.003]$} & {$[0.005]$} & {$[0.003]$} \\
\hline \multirow[t]{2}{*}{ Professional Cert. } & -0.004 & $0.024^{* * *}$ & $-0.028^{* *}$ & $-0.018^{* *}$ \\
\hline & {$[0.013]$} & {$[0.007]$} & {$[0.013]$} & {$[0.009]$} \\
\hline \multirow{2}{*}{ High school or less } & $0.027^{*}$ & $-0.017^{* *}$ & -0.023 & $-0.020^{*}$ \\
\hline & {$[0.015]$} & {$[0.008]$} & {$[0.015]$} & {$[0.010]$} \\
\hline \multirow[t]{2}{*}{ Family visa } & $0.044^{* *}$ & $0.021^{* *}$ & $0.057^{* * *}$ & $0.025^{* *}$ \\
\hline & {$[0.017]$} & {$[0.010]$} & {$[0.017]$} & {$[0.012]$} \\
\hline \multirow[t]{2}{*}{ Humanitarian visa } & $0.072^{* * *}$ & 0.009 & 0.021 & $0.040^{* *}$ \\
\hline & {$[0.027]$} & {$[0.015]$} & {$[0.027]$} & {$[0.018]$} \\
\hline Quarter of arrival & Yes & Yes & Yes & Yes \\
\hline Labor force status & Yes & Yes & Yes & Yes \\
\hline COB groups & Yes & Yes & Yes & Yes \\
\hline Interview state & Yes & Yes & Yes & Yes \\
\hline Observations & 2916 & 2916 & 2916 & 2916 \\
\hline
\end{tabular}

Used weights that correct for between wave attrition. Bachelor's and above and Skilled visa are omitted categories for education and visa status. Standard errors in brackets; * significant at $10 \%$; ** significant at $5 \%$; *** significant at $1 \%$ 
Table 5: Joint Significance test for Interaction terms in tables 3 and 4

\begin{tabular}{l|l}
\hline \hline \multicolumn{2}{c}{ Test for table 3 } \\
\hline $\begin{array}{l}\text { Null Hypothesis } \\
\text { chi2 }(4),[\text { Prob }>\text { chi2 }]\end{array}$ & $\begin{array}{l}\text { Muslim*Post 911 interaction terms are each equal to 0 } \\
6.05,[0.1952]\end{array}$ \\
\hline & \multicolumn{1}{c}{ Test for table 4 } \\
\hline $\begin{array}{l}\text { Null Hypothesis } \\
\text { chi2 (4), [Prob }>\text { chi2 }]\end{array}$ & $\begin{array}{l}\text { Muslim-like*Post 911 interaction terms are each equal to 0 } \\
24.51,[0.0001]\end{array}$
\end{tabular}

Table 6: Robustness checks for Perceptions

\begin{tabular}{|c|c|c|c|c|}
\hline Dependent variable & $\begin{array}{c}\text { Religious } \\
\text { intolerance } \\
(1)\end{array}$ & $\begin{array}{c}\text { Religious } \\
\text { discrimination } \\
(2)\end{array}$ & $\begin{array}{c}\text { Racial } \\
\text { intolerance } \\
(3)\end{array}$ & $\begin{array}{c}\text { Racial } \\
\text { discrimination } \\
(4)\end{array}$ \\
\hline \multicolumn{5}{|c|}{ Panel A: Narrowing window around 9/11, SUR } \\
\hline \multirow[t]{2}{*}{ Muslim-like } & $-0.160 * * *$ & 0.006 & $-0.213^{* * *}$ & 0.004 \\
\hline & {$[0.043]$} & {$[0.022]$} & {$[0.040]$} & {$[0.027]$} \\
\hline \multirow[t]{2}{*}{ Post 911} & -0.009 & -0.003 & $0.086^{* * *}$ & 0.022 \\
\hline & {$[0.035]$} & {$[0.018]$} & {$[0.032]$} & {$[0.022]$} \\
\hline \multirow[t]{2}{*}{ Muslim-like*Post911 } & $0.129 * * *$ & $0.082^{* * *}$ & 0.058 & 0.009 \\
\hline & {$[0.046]$} & {$[0.024]$} & [0.043] & {$[0.029]$} \\
\hline \multirow[t]{2}{*}{ Observations } & 1766 & 1766 & 1766 & 1766 \\
\hline & Panel B: & ine 5 cutoff, SU & & \\
\hline \multirow[t]{2}{*}{ Muslim-like } & $-0.113^{* * *}$ & 0.028 & $-0.090^{* *}$ & -0.032 \\
\hline & {$[0.042]$} & {$[0.024]$} & {$[0.043]$} & [0.029] \\
\hline \multirow[t]{2}{*}{ Post June 5} & 0.046 & $-0.091 * * *$ & $-0.062^{*}$ & $0.054^{* *}$ \\
\hline & {$[0.034]$} & {$[0.019]$} & {$[0.035]$} & {$[0.023]$} \\
\hline \multirow[t]{2}{*}{ Muslim-like*Post June 5} & 0.004 & -0.026 & $-0.058^{*}$ & $0.044^{* *}$ \\
\hline & {$[0.030]$} & {$[0.017]$} & {$[0.031]$} & {$[0.021]$} \\
\hline Observations & 1967 & 1967 & 1967 & 1967 \\
\hline
\end{tabular}

Both tests include other control variables included in Table 4. Used weights that correct for between wave attrition. Standard errors in brackets;

* significant at $10 \%$; ** significant at $5 \%$; $* * *$ significant at $1 \%$ 
Table 7: Testing Non-response, SUR

\begin{tabular}{|c|c|c|c|c|}
\hline \multicolumn{5}{|c|}{ Dependent variable: $1=$ Non-response, $0=$ Definitive response $\mid$ conditional on intervien } \\
\hline Non-response in & $\begin{array}{c}\text { Religious } \\
\text { intolerance } \\
\text { (1) }\end{array}$ & $\begin{array}{c}\text { Religious } \\
\text { discrimination } \\
(2)\end{array}$ & $\begin{array}{c}\text { Racial } \\
\text { intolerance } \\
(3)\end{array}$ & $\begin{array}{c}\text { Racial } \\
\text { discrimination } \\
(4)\end{array}$ \\
\hline \multicolumn{5}{|c|}{ Panel A: Interaction between Muslim and Post 9/11 } \\
\hline \multirow[t]{2}{*}{ Muslim } & -0.002 & -0.025 & $0.024^{*}$ & 0.020 \\
\hline & {$[0.015]$} & {$[0.020]$} & {$[0.012]$} & {$[0.014]$} \\
\hline \multirow[t]{2}{*}{ Post 911} & -0.010 & $-0.050^{*}$ & $0.060^{* * *}$ & 0.028 \\
\hline & {$[0.020]$} & {$[0.027]$} & {$[0.016]$} & {$[0.019]$} \\
\hline \multirow[t]{2}{*}{ Muslim*Post911 } & 0.052 & 0.023 & 0.041 & 0.028 \\
\hline & {$[0.032]$} & {$[0.043]$} & {$[0.026]$} & {$[0.029]$} \\
\hline \multirow[t]{2}{*}{ Ramadan } & -0.019 & -0.002 & -0.017 & -0.019 \\
\hline & {$[0.019]$} & {$[0.025]$} & {$[0.015]$} & {$[0.017]$} \\
\hline \multirow[t]{2}{*}{ Muslim*Ramadan } & -0.033 & -0.027 & -0.026 & -0.046 \\
\hline & {$[0.069]$} & {$[0.092]$} & {$[0.056]$} & {$[0.063]$} \\
\hline \multirow[t]{2}{*}{ Female } & $0.025^{* * *}$ & $0.050 * * *$ & $0.021 * * *$ & $0.027 * * *$ \\
\hline & {$[0.009]$} & {$[0.012]$} & {$[0.007]$} & {$[0.008]$} \\
\hline \multirow[t]{2}{*}{ Age } & $0.002^{* * *}$ & $0.003^{* * *}$ & $0.001^{* *}$ & $0.002^{* * *}$ \\
\hline & {$[0.000]$} & {$[0.001]$} & {$[0.000]$} & {$[0.000]$} \\
\hline \multirow[t]{2}{*}{ Speak English well } & $-0.066^{* * *}$ & $-0.069 * * *$ & $-0.046^{* * *}$ & $-0.087^{* * *}$ \\
\hline & {$[0.012]$} & {$[0.016]$} & {$[0.010]$} & {$[0.011]$} \\
\hline Observations & 3528 & 3528 & 3528 & 3528 \\
\hline \multicolumn{5}{|c|}{ Panel B: Interaction between Muslim-like and Post 9/11 } \\
\hline \multirow[t]{2}{*}{ Muslim-like } & -0.011 & 0.006 & -0.028 & -0.019 \\
\hline & {$[0.025]$} & {$[0.034]$} & {$[0.021]$} & {$[0.023]$} \\
\hline \multirow{2}{*}{ Post 911} & -0.018 & $-0.055^{* *}$ & $0.053^{* * *}$ & 0.021 \\
\hline & {$[0.020]$} & {$[0.027]$} & {$[0.017]$} & {$[0.019]$} \\
\hline \multirow[t]{2}{*}{ Muslim-like*Post911 } & $0.080^{* * *}$ & $0.073^{* *}$ & $0.067 * * *$ & $0.050^{*}$ \\
\hline & {$[0.028]$} & {$[0.037]$} & {$[0.023]$} & {$[0.026]$} \\
\hline \multirow{2}{*}{ Ramadan } & -0.018 & -0.009 & $-0.032^{*}$ & -0.015 \\
\hline & {$[0.020]$} & {$[0.027]$} & {$[0.016]$} & {$[0.018]$} \\
\hline \multirow{2}{*}{ Muslim-like*Ramadan } & -0.045 & 0.002 & 0.043 & -0.051 \\
\hline & {$[0.047]$} & {$[0.063]$} & {$[0.038]$} & {$[0.043]$} \\
\hline \multirow[t]{2}{*}{ Female } & $0.024^{* * *}$ & $0.050^{* * *}$ & $0.018^{* *}$ & $0.025^{* * *}$ \\
\hline & {$[0.009]$} & {$[0.012]$} & {$[0.007]$} & {$[0.008]$} \\
\hline \multirow[t]{2}{*}{ Age } & $0.002^{* * *}$ & $0.003^{* * *}$ & $0.001^{*}$ & $0.001^{* * *}$ \\
\hline & {$[0.000]$} & {$[0.001]$} & {$[0.000]$} & {$[0.000]$} \\
\hline \multirow[t]{2}{*}{ Speak English well } & $-0.067 * * *$ & $-0.068^{* * *}$ & $-0.048^{* * *}$ & $-0.089 * * *$ \\
\hline & {$[0.012]$} & {$[0.016]$} & {$[0.010]$} & {$[0.011]$} \\
\hline Observations & 3528 & 3528 & 3528 & 3528 \\
\hline
\end{tabular}

Includes other controls used in tables 3 and 4 . Used weights that correct for between wave attrition. Standard errors in brackets;

* significant at $10 \%$; ** significant at $5 \%$; *** significant at $1 \%$ 
Table 8: Perceptions after $9 / 11$ by gender, SUR

\begin{tabular}{|c|c|c|c|c|}
\hline Dependent variable & $\begin{array}{c}\text { Religious } \\
\text { intolerance } \\
(1)\end{array}$ & $\begin{array}{c}\text { Religious } \\
\text { discrimination } \\
(2) \\
\text { Males }\end{array}$ & $\begin{array}{c}\text { Racial } \\
\text { intolerance } \\
(3)\end{array}$ & $\begin{array}{c}\text { Racial } \\
\text { discrimination } \\
(4)\end{array}$ \\
\hline \multirow[t]{2}{*}{ Muslim } & -0.007 & -0.016 & -0.032 & -0.006 \\
\hline & {$[0.029]$} & {$[0.012]$} & {$[0.027]$} & [0.019] \\
\hline \multirow[t]{2}{*}{ Post 911} & -0.055 & 0.009 & -0.062 & $0.101^{* * *}$ \\
\hline & {$[0.040]$} & {$[0.017]$} & [0.039] & {$[0.026]$} \\
\hline \multirow[t]{2}{*}{ Muslim*Post911 } & $0.188^{* * *}$ & 0.008 & 0.022 & $0.080^{* *}$ \\
\hline & {$[0.062]$} & {$[0.026]$} & {$[0.060]$} & {$[0.041]$} \\
\hline \multirow[t]{2}{*}{ Observations } & 1398 & 1398 & 1398 & 1398 \\
\hline & & Females & & \\
\hline \multirow[t]{2}{*}{ Muslim } & 0.041 & -0.002 & -0.009 & -0.009 \\
\hline & {$[0.029]$} & [0.019] & {$[0.030]$} & {$[0.021]$} \\
\hline \multirow[t]{2}{*}{ Post 911} & 0.021 & $0.062^{* *}$ & $0.214^{* * *}$ & 0.028 \\
\hline & {$[0.038]$} & {$[0.025]$} & {$[0.039]$} & {$[0.027]$} \\
\hline \multirow[t]{2}{*}{ Muslim*Post911 } & -0.046 & 0.056 & -0.003 & 0.025 \\
\hline & {$[0.065]$} & {$[0.042]$} & {$[0.066]$} & {$[0.045]$} \\
\hline \multirow[t]{2}{*}{ Observations } & 1518 & 1518 & 1518 & 1518 \\
\hline & & Males & & \\
\hline \multirow[t]{2}{*}{ Muslim-like } & $-0.172^{* * *}$ & 0.003 & $-0.168^{* * *}$ & 0.003 \\
\hline & {$[0.051]$} & {$[0.021]$} & [0.049] & {$[0.033]$} \\
\hline \multirow[t]{2}{*}{ Post 911} & $-0.076^{*}$ & 0.006 & -0.056 & $0.099 * * *$ \\
\hline & {$[0.041]$} & {$[0.017]$} & [0.039] & {$[0.027]$} \\
\hline \multirow[t]{2}{*}{ Muslim-like*Post911 } & $0.227^{* * *}$ & $0.042^{*}$ & 0.023 & 0.055 \\
\hline & {$[0.053]$} & {$[0.022]$} & {$[0.051]$} & {$[0.035]$} \\
\hline \multirow[t]{2}{*}{ Observations } & 1398 & 1398 & 1398 & 1398 \\
\hline & & Females & & \\
\hline \multirow[t]{2}{*}{ Muslim-like } & -0.016 & 0.007 & -0.015 & -0.012 \\
\hline & {$[0.045]$} & {$[0.029]$} & {$[0.046]$} & {$[0.032]$} \\
\hline \multirow[t]{2}{*}{ Post 911} & 0.011 & $0.047^{*}$ & $0.211^{* * *}$ & 0.032 \\
\hline & {$[0.039]$} & {$[0.025]$} & {$[0.039]$} & {$[0.027]$} \\
\hline \multirow[t]{2}{*}{ Muslim-like*Post911 } & 0.025 & $0.120 * * *$ & 0.015 & 0.005 \\
\hline & {$[0.055]$} & {$[0.036]$} & {$[0.056]$} & {$[0.039]$} \\
\hline Observations & 1518 & 1518 & 1518 & 1518 \\
\hline
\end{tabular}

Regressions include other control variables included in tables 3 and 4 .

Used weights that correct for between wave attrition. Standard errors in brackets; * significant at $10 \%$; $* *$ significant at $5 \%$; *** significant at $1 \%$ 
Table 9: Looking for a change of main job conditional on working, Linear Probability Model

\begin{tabular}{|c|c|c|c|}
\hline Dep. Var: 1=Looking for anot & (1) & $\begin{array}{c}=\text { otherwise } \\
(2)\end{array}$ & $(3)$ \\
\hline \multirow{8}{*}{ Use Qualification in Main Job } & -0.089 & -0.091 & -0.092 \\
\hline & {$[0.069]$} & {$[0.071]$} & {$[0.069]$} \\
\hline & -0.059 & -0.066 & -0.069 \\
\hline & {$[0.068]$} & {$[0.071]$} & {$[0.069]$} \\
\hline & 0.137 & 0.137 & 0.139 \\
\hline & {$[0.188]$} & {$[0.190]$} & {$[0.189]$} \\
\hline & $0.167^{* * *}$ & $0.181^{* * *}$ & $0.143^{* * *}$ \\
\hline & {$[0.039]$} & [0.039] & {$[0.041]$} \\
\hline \multirow[t]{2}{*}{ Ramadan } & -0.024 & -0.021 & -0.022 \\
\hline & {$[0.064]$} & {$[0.067]$} & {$[0.066]$} \\
\hline \multirow[t]{2}{*}{ Muslim*Ramadan } & $0.536^{* * *}$ & $0.566^{* * *}$ & $0.487^{* *}$ \\
\hline & {$[0.199]$} & [0.202] & {$[0.202]$} \\
\hline \multirow[t]{2}{*}{ Network Job } & & $-0.061^{*}$ & $-0.073^{* *}$ \\
\hline & & {$[0.032]$} & {$[0.034]$} \\
\hline \multirow[t]{2}{*}{ Female } & -0.035 & -0.044 & -0.050 \\
\hline & {$[0.031]$} & {$[0.032]$} & {$[0.034]$} \\
\hline \multirow[t]{2}{*}{ Age } & $-0.005^{* * *}$ & $-0.005^{* *}$ & $-0.004^{* *}$ \\
\hline & {$[0.002]$} & {$[0.002]$} & {$[0.002]$} \\
\hline \multirow[t]{2}{*}{ Speak English well } & 0.004 & -0.006 & -0.009 \\
\hline & {$[0.053]$} & {$[0.055]$} & {$[0.056]$} \\
\hline \multirow[t]{2}{*}{ Principal applicant } & 0.035 & 0.033 & 0.043 \\
\hline & {$[0.041]$} & {$[0.042]$} & {$[0.043]$} \\
\hline \multirow[t]{2}{*}{ MU spouse in hhld } & 0.008 & 0.013 & 0.000 \\
\hline & {$[0.047]$} & {$[0.048]$} & [0.048] \\
\hline \multirow[t]{2}{*}{ Kids } & -0.000 & -0.001 & 0.004 \\
\hline & {$[0.016]$} & {$[0.016]$} & {$[0.016]$} \\
\hline \multirow[t]{2}{*}{ Months in Australia } & -0.004 & -0.004 & -0.003 \\
\hline & {$[0.012]$} & {$[0.012]$} & {$[0.012]$} \\
\hline \multirow[t]{2}{*}{ Professional Cert. } & $-0.079^{* *}$ & $-0.080^{* *}$ & $-0.095^{* *}$ \\
\hline & {$[0.036]$} & {$[0.037]$} & {$[0.040]$} \\
\hline \multirow[t]{2}{*}{ High School or Less } & 0.052 & 0.072 & 0.027 \\
\hline & {$[0.047]$} & [0.049] & {$[0.054]$} \\
\hline \multirow[t]{2}{*}{ Family visa } & -0.021 & -0.014 & -0.031 \\
\hline & {$[0.049]$} & {$[0.051]$} & {$[0.051]$} \\
\hline \multirow[t]{2}{*}{ Humanitarian visa } & $-0.158^{* *}$ & $-0.152^{*}$ & $-0.174^{* *}$ \\
\hline & {$[0.079]$} & {$[0.080]$} & {$[0.079]$} \\
\hline Quarter of arrival & Yes & Yes & Yes \\
\hline COB groups & Yes & Yes & Yes \\
\hline Interview state & Yes & Yes & Yes \\
\hline Occupation & No & No & Yes \\
\hline Observations (R-squared) & $1848(0.08)$ & $1782(0.09)$ & $1769(0.11)$ \\
\hline
\end{tabular}

Used weights that correct for between wave attrition. Bachelor's \& above, Skilled visa are omitted categories for education and visa status. Robust standard errors in brackets;

$*$ significant at $10 \% ; * *$ significant at $5 \% ; * * *$ significant at $1 \%$ 
Table 10: Looking for a change of main job conditional on working, Linear Probability Model

\begin{tabular}{|c|c|c|c|}
\hline \multicolumn{4}{|c|}{ Dep. Var: $1=$ Looking for another main job, $0=$ otherwise } \\
\hline \multirow{2}{*}{ Muslim like } & -0.125 & -0.132 & -0.132 \\
\hline & {$[0.101]$} & {$[0.100]$} & [0.099] \\
\hline \multirow[t]{2}{*}{ Post 911} & -0.043 & -0.049 & -0.050 \\
\hline & {$[0.069]$} & {$[0.071]$} & {$[0.070]$} \\
\hline \multirow[t]{2}{*}{ Muslim like*Post911 } & -0.157 & -0.160 & $-0.166^{*}$ \\
\hline & {$[0.097]$} & [0.099] & {$[0.100]$} \\
\hline \multirow[t]{2}{*}{ Use Qualification in Main Job } & $0.171^{* * *}$ & $0.186^{* * *}$ & $0.145^{* * *}$ \\
\hline & {$[0.038]$} & {$[0.039]$} & {$[0.041]$} \\
\hline \multirow[t]{2}{*}{ Ramadan } & -0.016 & -0.015 & -0.013 \\
\hline & {$[0.070]$} & {$[0.073]$} & {$[0.073]$} \\
\hline \multirow[t]{2}{*}{ Muslim like*Ramadan } & 0.241 & 0.258 & 0.220 \\
\hline & {$[0.171]$} & {$[0.175]$} & {$[0.163]$} \\
\hline \multirow[t]{2}{*}{ Network Job } & & $-0.058^{*}$ & $-0.071^{* *}$ \\
\hline & & {$[0.032]$} & {$[0.034]$} \\
\hline \multirow[t]{2}{*}{ Female } & -0.034 & -0.043 & -0.049 \\
\hline & {$[0.031]$} & {$[0.032]$} & {$[0.035]$} \\
\hline \multirow[t]{2}{*}{ Age } & $-0.005^{* *}$ & $-0.005^{* *}$ & $-0.004^{* *}$ \\
\hline & {$[0.002]$} & {$[0.002]$} & {$[0.002]$} \\
\hline \multirow[t]{2}{*}{ Speak English well } & -0.002 & -0.012 & -0.016 \\
\hline & {$[0.053]$} & {$[0.056]$} & {$[0.056]$} \\
\hline \multirow[t]{2}{*}{ Principal applicant } & 0.037 & 0.036 & 0.046 \\
\hline & {$[0.042]$} & [0.043] & {$[0.044]$} \\
\hline \multirow[t]{2}{*}{ MU spouse in hhld } & 0.015 & 0.020 & 0.006 \\
\hline & {$[0.047]$} & {$[0.048]$} & {$[0.048]$} \\
\hline \multirow[t]{2}{*}{ Kids } & -0.005 & -0.007 & -0.001 \\
\hline & {$[0.016]$} & {$[0.017]$} & {$[0.017]$} \\
\hline \multirow[t]{2}{*}{ Months in Australia } & -0.005 & -0.004 & -0.004 \\
\hline & {$[0.012]$} & {$[0.012]$} & {$[0.012]$} \\
\hline \multirow[t]{2}{*}{ Professional Cert. } & $-0.077^{* *}$ & $-0.078^{* *}$ & $-0.093^{* *}$ \\
\hline & {$[0.036]$} & {$[0.037]$} & {$[0.041]$} \\
\hline \multirow[t]{2}{*}{ High School or Less } & 0.050 & 0.069 & 0.021 \\
\hline & {$[0.047]$} & {$[0.050]$} & {$[0.054]$} \\
\hline \multirow[t]{2}{*}{ Family visa } & -0.021 & -0.014 & -0.033 \\
\hline & {$[0.049]$} & {$[0.051]$} & {$[0.051]$} \\
\hline \multirow[t]{2}{*}{ Humanitarian visa } & $-0.174^{* *}$ & $-0.170^{* *}$ & $-0.193^{* *}$ \\
\hline & {$[0.078]$} & {$[0.079]$} & {$[0.077]$} \\
\hline Quarter of arrival & Yes & Yes & Yes \\
\hline COB groups & Yes & Yes & Yes \\
\hline Interview state & Yes & Yes & Yes \\
\hline Occupation & No & No & Yes \\
\hline Observations (R-squared) & $1848(0.08)$ & $1782(0.08)$ & $1769(0.10)$ \\
\hline
\end{tabular}

Used weights that correct for between wave attrition. Bachelor's \& above, Skilled visa are omitted categories for education and visa status. Robust standard errors in brackets;

* significant at $10 \% ;{ }^{* *}$ significant at $5 \% ; * * *$ significant at $1 \%$ 
Table 11: Employment status in wave 2 conditional on being employed in wave1

\begin{tabular}{|c|c|c|c|}
\hline \multicolumn{3}{|c|}{ Dependent Variable: $1=$ Employed, $0=$ Not Employed } & $\overline{\overline{\text { red }}}$ \\
\hline \multirow[t]{2}{*}{ Muslim } & 0.121 & Muslim like & -0.053 \\
\hline & {$[0.086]$} & & {$[0.091]$} \\
\hline \multirow[t]{2}{*}{ Post 911} & -0.006 & Post 911 & -0.019 \\
\hline & {$[0.051]$} & & {$[0.052]$} \\
\hline \multirow[t]{2}{*}{ Muslim*Post911 } & 0.134 & Muslim like*Post911 & 0.134 \\
\hline & {$[0.206]$} & & {$[0.119]$} \\
\hline \multirow[t]{2}{*}{ Ramadan } & $-0.042^{*}$ & Ramadan & -0.036 \\
\hline & {$[0.022]$} & & {$[0.023]$} \\
\hline \multirow[t]{2}{*}{ Muslim*Ramadan } & -0.296 & Muslim like*Ramadan & -0.167 \\
\hline & {$[0.192]$} & & {$[0.113]$} \\
\hline \multirow[t]{2}{*}{ Female } & $0.049 * *$ & Female & $0.046^{*}$ \\
\hline & {$[0.024]$} & & {$[0.024]$} \\
\hline \multirow[t]{2}{*}{ Age } & $-0.004^{* *}$ & Age & $-0.004^{* *}$ \\
\hline & {$[0.002]$} & & {$[0.002]$} \\
\hline \multirow[t]{2}{*}{ Speak English well } & -0.008 & Speak English well & -0.008 \\
\hline & {$[0.052]$} & & {$[0.052]$} \\
\hline \multirow[t]{2}{*}{ Principal applicant } & -0.045 & Principal applicant & -0.042 \\
\hline & {$[0.034]$} & & {$[0.035]$} \\
\hline \multirow[t]{2}{*}{ MU spouse in hhld } & $0.053^{* *}$ & MU spouse in hhld & $0.055^{* *}$ \\
\hline & {$[0.026]$} & & {$[0.027]$} \\
\hline \multirow[t]{2}{*}{ Kids } & 0.006 & Kids & 0.006 \\
\hline & {$[0.011]$} & & {$[0.011]$} \\
\hline \multirow[t]{2}{*}{ Months in Australia } & -0.011 & Months in Australia & -0.010 \\
\hline & {$[0.011]$} & & {$[0.011]$} \\
\hline \multirow[t]{2}{*}{ Professional Cert. } & 0.013 & Professional Cert. & 0.012 \\
\hline & {$[0.024]$} & & {$[0.025]$} \\
\hline \multirow[t]{2}{*}{ High School or Less } & -0.018 & High School or Less & -0.009 \\
\hline & {$[0.035]$} & & {$[0.034]$} \\
\hline \multirow[t]{2}{*}{ Family visa } & $0.091^{* * *}$ & Family visa & $0.093^{* * *}$ \\
\hline & {$[0.029]$} & & {$[0.028]$} \\
\hline \multirow[t]{2}{*}{ Humanitarian visa } & $0.286^{* * *}$ & Humanitarian visa & $0.291 * * *$ \\
\hline & {$[0.101]$} & & {$[0.101]$} \\
\hline Quarter of arrival & Yes & Quarter of arrival & Yes \\
\hline COB groups & Yes & COB groups & Yes \\
\hline Interview state & Yes & Interview state & Yes \\
\hline Obs., (R sqaured) & $1418,(0.10)$ & Obs., (R sqaured) & $1418,(0.09)$ \\
\hline
\end{tabular}

Used weights that correct for between wave attrition. Bachelor's \& above, Skilled visa are omitted categories for education and visa status. Robust standard errors in brackets; * significant at $10 \%$; ** significant at $5 \%$; *** significant at $1 \%$ 
Table 12: Hours worked per week in main job

\begin{tabular}{|c|c|c|c|c|c|}
\hline \multicolumn{6}{|c|}{ Dependent Variable: Hours worked per week } \\
\hline \multirow[t]{2}{*}{ Muslim } & $-6.032^{* * *}$ & $-5.812^{* * *}$ & Muslim like & 1.493 & 0.749 \\
\hline & {$[2.127]$} & {$[2.020]$} & & {$[3.276]$} & [2.979] \\
\hline \multirow[t]{2}{*}{ Post 911} & $-5.661^{* *}$ & $-4.872^{* *}$ & Post 911 & $-5.568 * *$ & $-4.724^{* *}$ \\
\hline & {$[2.484]$} & {$[2.189]$} & & {$[2.450]$} & {$[2.163]$} \\
\hline \multirow[t]{2}{*}{ Muslim*Post911 } & 5.743 & 7.041 & Muslim like*Post911 & 4.529 & 3.889 \\
\hline & {$[5.309]$} & {$[5.009]$} & & {$[2.854]$} & {$[2.944]$} \\
\hline \multirow[t]{2}{*}{ Ramadan } & -1.604 & -1.778 & Ramadan & -1.237 & -1.689 \\
\hline & [1.854] & {$[1.870]$} & & {$[1.902]$} & [1.899] \\
\hline \multirow[t]{2}{*}{ Muslim*Ramadan } & -1.055 & 2.378 & Muslimlike*Ramadan & -4.966 & -1.695 \\
\hline & {$[8.755]$} & {$[8.764]$} & & {$[5.401]$} & {$[5.874]$} \\
\hline \multirow[t]{2}{*}{ Female } & $-8.459^{* * *}$ & $-7.453^{* * *}$ & Female & $-8.330 * * *$ & $-7.386^{* * *}$ \\
\hline & {$[0.810]$} & {$[0.824]$} & & {$[0.808]$} & {$[0.824]$} \\
\hline \multirow[t]{2}{*}{ Age } & -0.044 & -0.020 & Age & -0.041 & -0.017 \\
\hline & {$[0.072]$} & {$[0.070]$} & & {$[0.074]$} & {$[0.071]$} \\
\hline \multirow[t]{2}{*}{ Speak English well } & $-4.863^{* *}$ & $-4.617^{* *}$ & Speak English well & $-4.959 * *$ & $-4.719 * *$ \\
\hline & {$[2.293]$} & {$[2.105]$} & & {$[2.281]$} & {$[2.107]$} \\
\hline \multirow[t]{2}{*}{ Principal applicant } & 0.447 & -0.289 & Principal applicant & 0.359 & -0.307 \\
\hline & [1.060] & {$[1.068]$} & & {$[1.056]$} & [1.068] \\
\hline \multirow[t]{2}{*}{ MU spouse in hhld } & -2.370 & $-2.340^{*}$ & MU spouse in hhld & $-2.503^{*}$ & $-2.413^{*}$ \\
\hline & {$[1.457]$} & {$[1.412]$} & & {$[1.471]$} & {$[1.424]$} \\
\hline \multirow[t]{2}{*}{ Kids } & $-1.278^{* * *}$ & $-1.298^{* * *}$ & Kids & $-1.259 * * *$ & $-1.302^{* * *}$ \\
\hline & {$[0.435]$} & {$[0.429]$} & & {$[0.446]$} & {$[0.440]$} \\
\hline \multirow[t]{2}{*}{ Months in Australia } & 0.287 & 0.308 & Months in Australia & 0.266 & 0.287 \\
\hline & [0.323] & [0.309] & & {$[0.327]$} & {$[0.313]$} \\
\hline \multirow[t]{2}{*}{ Professional Cert. } & 0.446 & 0.878 & Professional Cert. & 0.470 & 0.907 \\
\hline & [1.041] & [1.143] & & {$[1.036]$} & [1.139] \\
\hline High School & -1.105 & 0.299 & High School & -1.616 & -0.189 \\
\hline or Less & [1.339] & [1.260] & or Less & [1.343] & {$[1.252]$} \\
\hline \multirow[t]{2}{*}{ Family visa } & $-3.098 * * *$ & -1.947 & Family visa & $-3.274^{* * *}$ & $-2.138^{*}$ \\
\hline & [1.177] & [1.198] & & [1.184] & {$[1.205]$} \\
\hline \multirow[t]{2}{*}{ Humanitarian visa } & $-7.054^{* * *}$ & $-5.003^{* *}$ & Humanitarian visa & $-7.045^{* * *}$ & $-5.140 * *$ \\
\hline & {$[2.137]$} & {$[2.116]$} & & {$[2.181]$} & {$[2.129]$} \\
\hline Quarter of arrival & Yes & Yes & Quarter of arrival & Yes & Yes \\
\hline COB groups & Yes & Yes & COB groups & Yes & Yes \\
\hline Interview state & Yes & Yes & Interview state & Yes & Yes \\
\hline Occupation & No & Yes & Occupation & No & Yes \\
\hline Obs., (R-squared) & $1830,(0.20)$ & $1830,(0.24)$ & Obs., (R-squared) & $1830,(0.19)$ & $1830,(0.24)$ \\
\hline
\end{tabular}

Used weights that correct for between wave attrition. Bachelor's \& above, Skilled visa are omitted categories for education and visa status. Robust standard errors in brackets; * significant at $10 \%$; $*$ significant at $5 \% ;{ }^{* * *}$ significant at $1 \%$ 
Table 13: Wage Income per week, Ordered Probit MLE

\begin{tabular}{|c|c|c|c|c|c|}
\hline \multicolumn{6}{|c|}{ Dependent Variable: Interval Coded Income from Wages } \\
\hline & $(1)$ & $(2)$ & & $(3)$ & (4) \\
\hline \multirow[t]{2}{*}{ Muslim } & $-0.253^{*}$ & $-0.224^{*}$ & Muslim like & 0.236 & 0.211 \\
\hline & {$[0.137]$} & {$[0.131]$} & & {$[0.178]$} & {$[0.164]$} \\
\hline \multirow[t]{2}{*}{ Post 911} & $-0.222^{* *}$ & $-0.167^{*}$ & Post 911 & $-0.203^{*}$ & -0.151 \\
\hline & {$[0.110]$} & {$[0.096]$} & & {$[0.107]$} & {$[0.093]$} \\
\hline \multirow[t]{2}{*}{ Muslim*Post911 } & -0.084 & -0.033 & Muslim like*Post911 & -0.021 & -0.021 \\
\hline & {$[0.315]$} & {$[0.336]$} & & {$[0.164]$} & {$[0.165]$} \\
\hline \multirow[t]{2}{*}{ Ramadan } & -0.030 & -0.059 & Ramadan & -0.024 & -0.056 \\
\hline & {$[0.090]$} & {$[0.092]$} & & {$[0.088]$} & {$[0.090]$} \\
\hline \multirow{2}{*}{ Muslim*Ramadan } & -0.156 & 0.086 & Muslim*Ramadan & $-0.464^{* *}$ & -0.152 \\
\hline & {$[0.329]$} & {$[0.376]$} & & {$[0.209]$} & {$[0.240]$} \\
\hline \multirow[t]{2}{*}{ Female } & $-0.407 * * *$ & $-0.353^{* * *}$ & Female & $-0.398 * * *$ & $-0.346^{* * *}$ \\
\hline & {$[0.042]$} & {$[0.041]$} & & {$[0.042]$} & {$[0.042]$} \\
\hline \multirow[t]{2}{*}{ Age } & 0.001 & -0.000 & Age & 0.001 & 0.000 \\
\hline & {$[0.003]$} & {$[0.003]$} & & {$[0.003]$} & {$[0.003]$} \\
\hline \multirow[t]{2}{*}{ Speak English well } & 0.010 & 0.020 & Speak English well & 0.013 & 0.024 \\
\hline & {$[0.086]$} & {$[0.078]$} & & {$[0.086]$} & {$[0.078]$} \\
\hline \multirow[t]{2}{*}{ Principal applicant } & $0.098^{*}$ & -0.022 & Principal applicant & 0.089 & -0.027 \\
\hline & {$[0.058]$} & {$[0.056]$} & & {$[0.058]$} & {$[0.056]$} \\
\hline \multirow[t]{2}{*}{ MU spouse in hhld } & -0.050 & -0.001 & MU spouse in hhld & -0.058 & -0.006 \\
\hline & {$[0.065]$} & {$[0.062]$} & & {$[0.066]$} & {$[0.062]$} \\
\hline \multirow[t]{2}{*}{ Kids } & -0.026 & $-0.048^{* *}$ & Kids & -0.025 & $-0.048^{* *}$ \\
\hline & {$[0.022]$} & {$[0.021]$} & & {$[0.022]$} & {$[0.021]$} \\
\hline \multirow[t]{2}{*}{ Months in Australia } & 0.022 & 0.012 & Months in Australia & 0.021 & 0.010 \\
\hline & {$[0.017]$} & {$[0.016]$} & & {$[0.017]$} & {$[0.016]$} \\
\hline \multirow[t]{2}{*}{ Professional Cert. } & $-0.317 * * *$ & $-0.185^{* * *}$ & Professional Cert. & $-0.313^{* * *}$ & $-0.180 * * *$ \\
\hline & [0.049] & {$[0.048]$} & & [0.048] & [0.048] \\
\hline \multirow[t]{2}{*}{ High School or Less } & $-0.351 * * *$ & $-0.199^{* * *}$ & High School or Less & $-0.370 * * *$ & $-0.217 * * *$ \\
\hline & {$[0.063]$} & {$[0.061]$} & & [0.063] & {$[0.061]$} \\
\hline \multirow[t]{2}{*}{ Family visa } & $-0.209 * * *$ & -0.033 & Family visa & $-0.219 * * *$ & -0.041 \\
\hline & {$[0.066]$} & [0.059] & & {$[0.066]$} & {$[0.059]$} \\
\hline \multirow[t]{2}{*}{ Humanitarian visa } & $-0.499 * * *$ & $-0.311 * * *$ & Humanitarian visa & $-0.480 * * *$ & $-0.297^{* * *}$ \\
\hline & {$[0.110]$} & {$[0.106]$} & & {$[0.111]$} & [0.105] \\
\hline Quarter of arrival & Yes & Yes & Quarter of arrival & Yes & Yes \\
\hline COB groups & Yes & Yes & COB groups & Yes & Yes \\
\hline Interview state & Yes & Yes & Interview state & Yes & Yes \\
\hline Occupation & No & Yes & Occupation & No & Yes \\
\hline Observations & 1736 & 1660 & Observations & 1736 & 1660 \\
\hline
\end{tabular}

Used weights that correct for between wave attrition. Bachelor's \& above, Skilled visa are omitted categories for education and visa status. Robust standard errors in brackets; * significant at $10 \% ;{ }^{* *}$ significant at $5 \% ; * * *$ significant at $1 \%$ 
Table 14: Attrition Indicators (PA only) ${ }^{1}$

\begin{tabular}{r|ccccc}
\hline \hline & Full sample & Muslim & Non-Muslim & Muslim-like & Non-Muslim-like \\
& $(1)$ & $(2)$ & $(3)$ & $(4)$ & $(5)$ \\
Interviewed in wave2 & 85.86 & 85.92 & 85.86 & 92.57 & 83.83 \\
Unable to track & 4.26 & 6.87 & 3.89 & 3.63 & 4.45 \\
Refused & 3.2 & 1.84 & 3.39 & 0.97 & 3.88 \\
Overseas temporarily & 3.22 & 2.23 & 3.35 & 1.18 & 3.83 \\
Overseas permanently & 1.67 & 1.58 & 1.68 & 0.83 & 1.92 \\
Australia-out of scope & 0.72 & 0.09 & 0.81 & 0.05 & 0.92 \\
Other & 1.08 & 1.48 & 1.02 & 0.78 & 1.17 \\
Total & 100 & 100 & 100 & 100 & 100 \\
Sample size & 3124 & 367 & 2757 & 691 & 2433 \\
\hline
\end{tabular}

1 Used weights that do not correct for attrition.

2 Living in a non-urban area, too distant to be interviewed.

Table 15: Religious identity by survey period ${ }^{1}$

\begin{tabular}{|c|c|c|c|c|c|}
\hline \multicolumn{4}{|c|}{ wave2 } & \multicolumn{2}{|c|}{ wave1 } \\
\hline \multirow{3}{*}{$\begin{array}{r}\text { Non-Muslim } \\
\text { Muslim }\end{array}$} & Pre $9 / 11$ & Post $9 / 11$ & \multirow{3}{*}{$\begin{array}{r}\text { Non-Muslim } \\
\text { Muslim }\end{array}$} & Pre Aug/16 & Post Aug/16 \\
\hline & 0.65 & 0.23 & & 0.62 & 0.26 \\
\hline & 0.09 & 0.02 & & 0.09 & 0.03 \\
\hline \multicolumn{3}{|c|}{ wave2 } & & \multicolumn{2}{|c|}{ wave1 } \\
\hline \multirow{3}{*}{$\begin{array}{r}\text { Non-Muslim-like } \\
\text { Muslim-like }\end{array}$} & Pre $9 / 11$ & Post $9 / 11$ & \multirow{3}{*}{$\begin{array}{r}\text { Non-Muslim-like } \\
\text { Muslim-like }\end{array}$} & Pre Aug/16 & Post Aug/16 \\
\hline & 0.55 & 0.20 & & 0.54 & 0.23 \\
\hline & 0.20 & 0.06 & & 0.17 & 0.06 \\
\hline
\end{tabular}

1 Used weights that do not correct for attrition. 